\title{
Spontaneous hemothorax associated with neurofibromatosis type I: A review of the literature
}

\author{
Swaroopa Pulivarthi, Byron Simmons ${ }^{1}$, John Shearen², Murali Krishna Gurram³
}

Departments of Research, ${ }^{1}$ Pathology, ${ }^{2}$ Minnesota Surgical Associates, ${ }^{3}$ Internal Medicine, Health East Care System, Saint Paul, Minnesota, USA

\section{ABSTRACT}

Neurofibromatosis is generally a benign disease, but has the potential for rare and fatal complications, such as spontaneous hemothorax. We report a case of massive hemothorax due to neurofibroma in a 49-year-old woman with neurofibromatosis type 1 . The configuration of the radiological opacity and frank blood withdrawn on thoracentesis should suggest the diagnosis of hemothorax in a patient with neurofibromatosis. Surgical treatment for hemothorax is limited by arterial fragility and the prognosis is relatively poor. Any evidence of aneurysmal disease in the thoracic vessels should be aggressively managed percutaneously by coil embolization to prevent future rupture.

Key words: Neurofibroma, neurofibromatosis type I, spontaneous hemothorax

\section{Introduction}

Neurofibromatosis type I (NF-I) also known as Von Recklinghausen's disease, is an autosomal dominant disorder that involves abnormal growth of neuroectodermal tumors in the peripheral nervous system. The incidence of NF-I is one in 3000 individuals. NF-I is due to mutations in the neurofibromin-encoding gene that is located on chromosome 17q11.2 with characteristic variable penetration. ${ }^{[1]}$ These mutations lead to the formation of neurofibromas of the peripheral nervous system with $50 \%$ of cases resulting from spontaneous mutations. ${ }^{[1]}$ Spontaneous hemothorax is one of the uncommon complications of NF-I and is potentially fatal. The expected mediastinal tumor in Von Recklinghausen's disease is a tumor of nerve sheath origin, namely, neurofibroma, and $4 \%$ of patients with this disease develop malignant schwannoma, which has been reported to cause massive hemothorax. ${ }^{[2]}$ We are describing a case of spontaneous hemothorax due to neurofibroma in a patient with a history of NF-I.

\begin{tabular}{|l|l|}
\hline \multicolumn{2}{|c|}{ Access this article online } \\
\hline Quick Response Code: & Website: \\
\hline & www.ruralneuropractice.com \\
\cline { 2 - 2 } & \\
\hline & DOI: \\
\hline
\end{tabular}

\section{Case Report}

A 49-year-old woman with a history of asthma, NF-I, and chronic smoking presented to the emergency room with chest pain. It was sudden onset of sharp, continuous pain in the right upper chest and radiating to the right lower chest, moderate in intensity, exacerbated with inspiration and cough. Her family history was positive for NF-1. Physical examination revealed the presence of decreased breath sounds at the base of the right lung. She had neurofibromas all over the skin. Computed tomography of the chest confirmed the presence of a large amount of right pleural effusion with mediastinal shift [Figure 1].

Thoracentesis was done without successful drainage. Her hemoglobin dropped gradually from $11.2 \mathrm{mg} / \mathrm{dL}$ to $9.6 \mathrm{mg} / \mathrm{dL}$. She underwent right thoracoscopy with evacuation of $2700 \mathrm{~mL}$ of blood. During the procedure, an apical mass with sentinel clot was demonstrated. The frozen section reported the absence of malignancy. We were unable to find the exact source of bleeding. Histology showed the segments of hyperplastic nerve tissue, consisting of cells that were S-100-positive by immunohistochemistry, confirming the diagnosis of neurofibroma [Figure 2]. The patient improved after surgery and she was discharged to home in stable condition.

\section{Address for correspondence:}

Dr. Murali Krishna Gurram, $4510^{\text {th }}$ Street West, Saint Paul, Minnesota - 55102, USA.

E-mail: gmk_doctor@yahoo.co.uk 


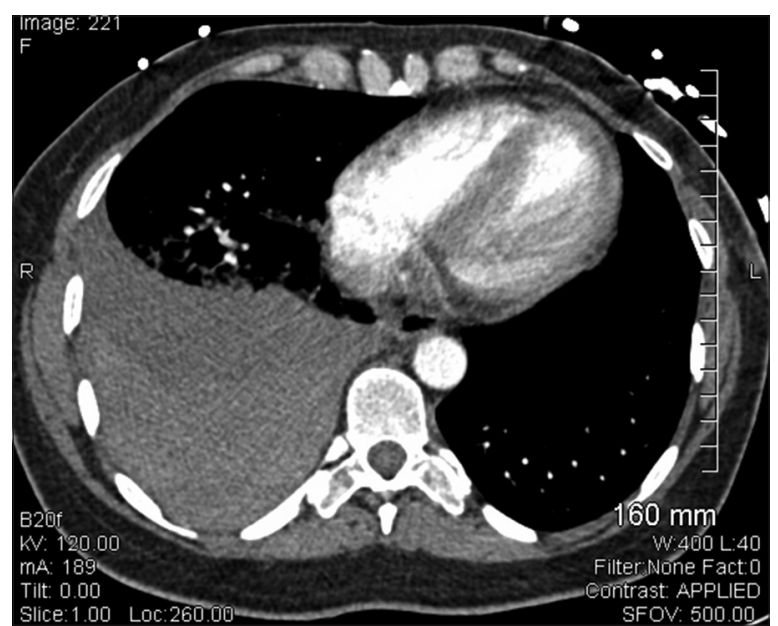

Figure 1: Computed tomography of chest showing large amount of right pleural effusion and mediastinal shift to the left

\section{Discussion}

Spontaneous hemothorax is a rare and often lethal complication of NF-I. Two different types of vasculopathy have been described: Stenosis or aneurysmal modifications of large intrathoracic vessels, most commonly the subclavian artery and the intercostal arteries; and dysplastic alterations of small vessels in highly vascularized mesenchymal tumors. ${ }^{[3]}$ Most commonly, tumor-related hemothorax is due to neurofibroma, and the most frequently involved artery is the intercostal artery.

Of the 11 published studies as shown in Table 1, nine patients underwent surgical exploration with two postoperative deaths. ${ }^{[2,4]}$ However, the sudden death without operation was also reported in two patients with NF-1. ${ }^{[5,6]}$ Sudden death occurred in a patient with spontaneous hemothorax due to neurofibroma causing a compression fracture of the thoracic vertebrae that in turn led to laceration of the aorta ${ }^{[6]}$ In another case report, immediate death following spontaneous hemothorax during the postpartum period in a 37-year-old female with history of NF-I, due to rupture of right subclavian artery by infiltrating neurofibromas. ${ }^{[5]}$ In a review article by Miura et al., in 2005, of seven patients with spontaneous hemothorax, the histology of tumors included five benign tumors (one benign schwannoma and four neurofibromas) and two malignant tumors (one malignant schwannoma and one neurofibrosarcoma). ${ }^{[7]}$

In the case report described by Lim et al., an 18-year-old male had partial excision of a large hemorrhagic mediastinal tumor and it was diagnosed as neurofibrosarcoma. ${ }^{[8]}$ Another case presented with spontaneous hemothorax due to mediastinal

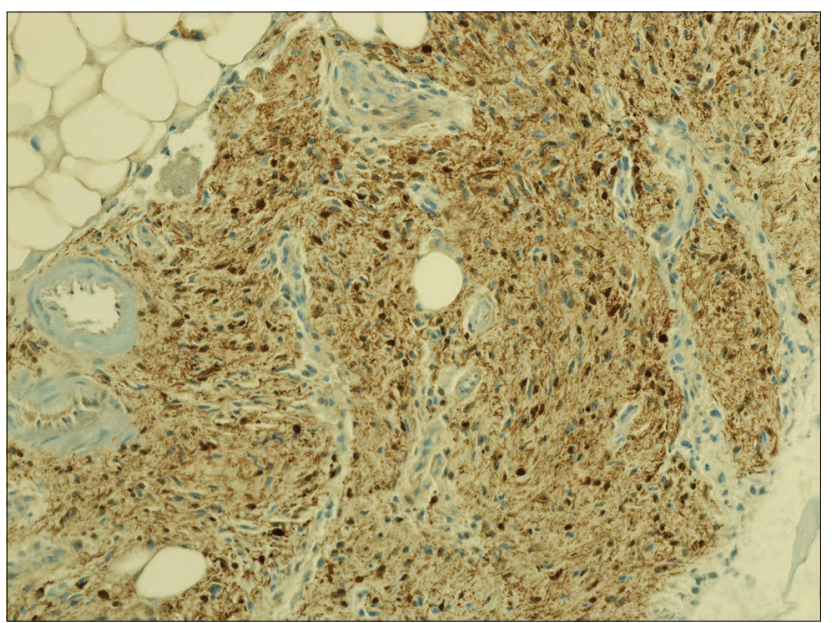

Figure 2: Histology section showing the segments of hyperplastic nerve tissue consisting of cells that are S-100 (+) by immunohistochemistry

tumor was also managed with excision and it was a benign schwannoma. ${ }^{[9]}$ Vaziri et al. managed their patient with exploratory thoracotomy, which showed continuous bleeding from tumor vessels (confirmed as ganglioneuroma), and they were unable to achieve a stable hemodynamic status despite the transfusion of eight units of blood and they packed the area with three large laparotomy pads. ${ }^{[10]}$ Three weeks later an uneventful re-thoracotomy showed the disappearance of the tumor perhaps due to the rupture and losing its vascular supply leading to necrosis or degeneration. ${ }^{[10]}$ The patient has been followed for two years without any complications.

In another case reported by Fedoruk et al., there was disruption of the left subclavian artery and left internal thoracic artery junction, and exploratory thoracotomy revealed tissue masses and clots. ${ }^{[11]}$ As these vessels were friable and brittle, multiple attempts at a primary suture repair were made, and the artery was over sewn. Faruque et al. described a patient with neurofibromatosis who developed massive hemothorax as a result of spontaneous rupture of the left vertebral artery and left subclavian artery due to invasion by neurofibromas. ${ }^{[12]}$ They successfully managed the patient with a combination of surgical and interventional radiology techniques, stapling of the left subclavian artery and endovascular embolization of left vertebral artery.

Another patient presented with spontaneous hemothorax due to an unknown source of bleeding as observed in our case, managed with recombinant-activated VII factor (Novoseven $90 \mu / \mathrm{kg}$ ) after an unsuccessful surgical attempt to stop bleeding. ${ }^{[3]}$ The patient's bleeding was well controlled after the infusion of recombinant-activated VII factor for three times. 
Table 1: Previously published articles on spontaneous hemothorax due to bleeding from the vascularized mesenchymal tumors

\begin{tabular}{|c|c|c|c|c|c|}
\hline Author (year) & Age/gender & Location of bleeding & Tumor & Treatment & Outcome \\
\hline Larrieu et al. ${ }^{[9]}$ (1982) & 44/female & $\begin{array}{l}\text { Right intercostal artery } \\
\text { and vein }\end{array}$ & $\begin{array}{l}\text { Benign } \\
\text { schwannoma }\end{array}$ & $\begin{array}{l}\text { Chest tube drainage, exploratory } \\
\text { thoracotomy, excision and } \\
\text { ligation }\end{array}$ & Alive \\
\hline Brady et al. ${ }^{[5]}(1984)$ & 37/female & Right subclavian artery & Neurofibroma & No & Dead \\
\hline Lim et al. ${ }^{[8]}(1990)$ & 18/male & Left intercostal artery & Neurofibrosarcoma & $\begin{array}{l}\text { Chest tube drainage, exploratory } \\
\text { thoracotomy, partial excision } \\
\text { and ligation }\end{array}$ & Alive \\
\hline Fuyuno et al. ${ }^{[2]}$ (1995) & $17 /$ male & Left subphrenic artery & $\begin{array}{l}\text { Malignant } \\
\text { schwannoma }\end{array}$ & Exploratory thoracotomy & Dead \\
\hline Baldo et al. ${ }^{[4]}(2003)$ & $33 /$ male & Right subclavian artery & Neurofibroma & $\begin{array}{l}\text { Chest tube drainage, exploratory } \\
\text { thoracotomy }\end{array}$ & Dead \\
\hline Miura et al. ${ }^{[7]}(2005)$ & 59/female & Left intercostal artery & Neurofibroma & $\begin{array}{l}\text { Exploratory thoracotomy, } \\
\text { excision and ligation }\end{array}$ & Alive \\
\hline Vaziri et al. ${ }^{[10]}(2006)$ & 30/female & $\begin{array}{l}\text { Right tumor vessels } \\
\text { rupture }\end{array}$ & Ganglioneuroma & $\begin{array}{l}\text { Chest tube drainage, exploratory } \\
\text { thoracotomy and packing. } \\
\text { Exploratory thoracotomy at } \\
3 \text { weeks-no obvious lesion to } \\
\text { resect }\end{array}$ & Alive \\
\hline Radeschi et al. ${ }^{\left[{ }^{[3]}\right.}(2007)$ & 36/female & $\begin{array}{l}\text { Right side, unknown } \\
\text { source }\end{array}$ & Neurofibroma & $\begin{array}{l}\text { Chest tube drainage, } \\
\text { recombinant activated factor VII }\end{array}$ & Alive \\
\hline Fedoruk et al..$^{[11]}(2007)$ & 48/female & $\begin{array}{l}\text { Junction of left subclavian } \\
\text { and left internal thoracic } \\
\text { artery disruption }\end{array}$ & Neurofibroma & $\begin{array}{l}\text { Chest tube drainage, exploratory } \\
\text { thoracotomy }\end{array}$ & Alive \\
\hline Fernandez-Flores et al. ${ }^{[6]}(2008)$ & 28/male & Laceration of aorta & Neurofibroma & No & Dead \\
\hline Faruque et al. ${ }^{[12]}(2009)$ & 31/female & $\begin{array}{l}\text { Left subclavian artery } \\
\text { and left vertebral artery } \\
\text { rupture }\end{array}$ & Neurofibroma & $\begin{array}{l}\text { Chest tube drainage, exploratory } \\
\text { thoracotomy, stapling of the } \\
\text { subclavian artery, embolization } \\
\text { and sclerosis of vertebral artery }\end{array}$ & Alive \\
\hline The presented case (2012) & 49/female & $\begin{array}{l}\text { Right side, unknown } \\
\text { source }\end{array}$ & Neurofibroma & $\begin{array}{l}\text { Thoracoscopy and excision of } \\
\text { tumor }\end{array}$ & Alive \\
\hline
\end{tabular}

\section{Conclusion}

We emphasize the importance of consideration of spontaneous hemothorax and mediastinal tumor in the differential diagnosis in any patient with a history of neurofibromatosis type I, who presents with chest pain and pleural effusion. Early diagnosis and intervention is critical to prevent mortality. Spontaneous massive hemothorax in a patient with neurofibromatosis type I is due to erosion of thoracic vessels by tumor or from degeneration of a hypervascular neural tumor.

\section{References}

1. Riccardi VM. Neurofibromatosis: Past, present, and future. N Engl J Med 1991;324:1283-5.

2. Fuyuno G, Kobayashi R, Iga R, Horio H, Nomori H, Kodera K, et al. A case of Von Recklinghausen's disease associated with a hemothorax due to a rapidly growing malignant schwannoma. Nihon Kyobu Shikkan Gakkai Zasshi 1995;33:682-5.

3. Radeschi G, Boris EF, Sega P, Odetto L, Venturino S. Utilization of recombinant activated factor VII in a case of spontaneous massive haemothorax in a patient with Von Recklinghausen's disease. Minerva
Anestesiol 2007;73:241-4.

4. Baldó X, Ortiz MR, Sebastián F, Bernadó L. Fatal right spontaneous haemothorax in Von Recklinghausen's disease. Interact Cardiovasc Thorac Surg 2003;2:35-7.

5. Brady DB, Bolan JC. Neurofibromatosis and spontaneous hemothorax in pregnancy: Two case reports. Obstet Gynecol 1984;63(Suppl 3):35S-8S.

6. Fernandez-Flores A, Orduña O, Aguirrezabal M. Café-au-lait macules: Occasional fatal sequels of benign pigmented lesions. Acta Dermatovenerol Croat 2008;16:79-82.

7. Miura T, Kawano Y, Chujo M, Miyawaki M, Mori H, Kawahara K. Spontaneous hemothorax in patients with von Recklinghausen's disease. Jpn J Thorac Cardiovasc Surg 2005;53:649-52.

8. Lim R, de Souza AD, Beggs D. Neurofibrosarcoma presenting as spontaneous haemothorax. Br J Clin Pract 1990;44:289-91.

9. Larrieu AJ, Hashimoto SA, Allen P. Spontaneous massive haemothorax in von Recklinghausen's disease. Thorax 1982;37:151-2.

10. Vaziri M, Mehrazma M. Massive spontaneous hemothorax associated with Von Recklinghausen's disease. Ann Thorac Surg 2006;82:1500-1.

11. Fedoruk LM, English J, Fradet GJ. Spontaneous hemothorax and neurofibromatosis: A review of a lethal combination. Asian Cardiovasc Thorac Ann 2007;15:342-4.

12. Faruque MO, Davidson F. Clinical challenges and serious vascular complications in neurofibromatosis. Emerg Med Australas 2009;21:518-20.

How to cite this article: Pulivarthi S, Simmons B, Shearen J, Gurram MK. Spontaneous hemothorax associated with neurofibromatosis type I: A review of the literature. J Neurosci Rural Pract 2014;5:269-71.

Source of Support: Nil. Conflict of Interest: None declared. 